УДК 330.357

DOI 10.18101/2304-4446-2019-2-66-76

\title{
АНАЛИЗ СОВРЕМЕННОГО СОСТОЯНИЯ И ДИНАМИКИ РАЗВИТИЯ СЕЛЬСКОГО ХОЗЯЙСТВА И ЛЕКАРСТВЕННОГО РАСТЕНИЕВОДСТВА В РОССИИ
}

\author{
(С) Раднаева Светлана Эрнстовна \\ кандидат экономических наук \\ E-mail: radnasv@gmail.com \\ (C) Мункуева Ирина Сергеевна \\ кандидат экономических наук, доцент \\ E-mail: mishka81@yandex.ru \\ (C) Санжиева Дарима Дашидоржиевна \\ кандидат экономических наук \\ E-mail: daricha.s@mail.ru
}

Бурятский государственный университет имени Доржи Банзарова

Россия, 670000, г. Улан-Удэ, ул. Смолина, 24a

В статье проводится анализ современного состояния и динамики развития сельского хозяйства Российской Федерации и его подотрасли - лекарственного растениеводства. Приведены основные показатели сельского хозяйства России на последние 10 лет, отражающие активное развитие отрасли, рост валовой добавленной стоимости, значительное увеличение инвестиций в основной капитал и финансовых вложений, рекордные объемы экспорта зерновых культур.

Выявлены тенденции развития сельского хозяйства: стратегии сельхозпроизводителей, направленные на сокращение расходов, увеличение объемов производства, выход на новые рынки и др. Произведена оценка основных показателей лекарственного растениеводства, такие как посевные площади, валовые сборы и урожайность лекарственных и эфирномасличных культур за последние 7 лет. Определены основные проблемы и предпосылки возрождения лекарственного растениеводства в рамках реализации Дорожной карты «Хелснет» Национальной технологической инициативы.

Ключевые слова: сельское хозяйство; лекарственное растениеводство; лекарственное растительное сырье; дорожная карта «Хелснет» НТИ.

\section{Для цитирования:}

Раднаева С. Э., Мункуева И. С., Санжиева Д. Д. Анализ современного состояния и динамики развития сельского хозяйства и лекарственного растениеводства в России // Вестник Бурятского государственного университета. Экономика и менеджмент. 2019. № 2. С. 66-76.

Сельское хозяйство в России - это одна из крупных и стратегически важных сфер экономики, включающая две основные подотрасли (растениеводство и животноводство) и направленная на полное обеспечение населения продовольственными товарами, получения сырья для отдельных областей промышленности. 
С. Э. Раднаева, И. С. Мункуева, Д. Д. Санжиева. Анализ современного состояния и динамики развития сельского хозяйства и лекарственного растениеводства в России

Так, основными целями Государственной программы развития сельского хозяйства и регулирования рынков сельскохозяйственной продукции, сырья и продовольствия на 2013-2020 гг. являются обеспечение продовольственной независимости России в параметрах, заданных Доктриной продовольственной безопасности Российской Федерации, утвержденной Указом Президента Российской Федерации от 30 января 2010 г. № 120; и ускоренное импортозамещение и повышение конкурентоспособности российской сельскохозяйственной продукции на внутреннем и внешнем рынках.

Сельское хозяйство отличается от других отраслей экономики сезонным характером производства, использованием земли как предмета и средства труда, высокой зависимостью от природно-климатических и экономических условий, а также достаточного наличия воды.

Сельское хозяйство является важнейшей составной частью агропромышленного комплекса (АПК), в который помимо хозяйств, непосредственно связанных с разработкой природных ресурсов, входят отрасли обрабатывающей промышленности, производящие средства производства для сельского хозяйства (машины, удобрения и др.) и перерабатывающие сельскохозяйственное сырье в конечную потребительскую продукцию.

Из важных экономических факторов развития сельского хозяйства являются рыночные цены, себестоимость продукции, а также содействие государства в виде субсидий, кредитования и регулирования производства во избежание перенасыщения одними продуктами и недостатка в других.

Сельское хозяйство как важнейшая сфера мировой экономики представляет собой комплекс отраслей (растениеводство, животноводство, рыболовство, лесное хозяйство, промыслы), связанных с разработкой растительных и животных ресурсов. Отрасль активными темпами развивается в большинстве стран мира, хотя в настоящее время для мирового хозяйства характерна постиндустриальная структура, в которой преобладают отрасли непроизводственной сферы, особенно в развитых странах. В области материального производства лидирующие позиции в совокупном валовом внутреннем продукте (ВВП) занимает именно промышленность, ее показатель составляет порядка $35 \%$ ВВП, сельское хозяйство $-4 \%$, строительство - $6 \%$, транспортная сфера $-10 \%$.

Доля сельского хозяйства, охоты и лесного хозяйства ${ }^{1}$ в ВВП России за 10 лет демонстрировала нестабильную динамику. Однако начиная с 2012 г. наблюдается умеренный рост, а за последние три года доля отрасли в ВВП России (в текущих ценах) [10] увеличилась на $0,78 \%$ и составила $4,0 \%$ в 2016 г.

\footnotetext{
${ }^{1}$ В системе национальных счетов РФ (СНC), основанной на методологических положениях, разработанных совместно ООН, ВМФ, Всемирным банком, ОЭСР и Евростатом и разработанной Росстатом РФ, при расчете валового внутреннего продукта применяются группировки национальной экономики на укрупненные отрасли народного хозяйства.
} 


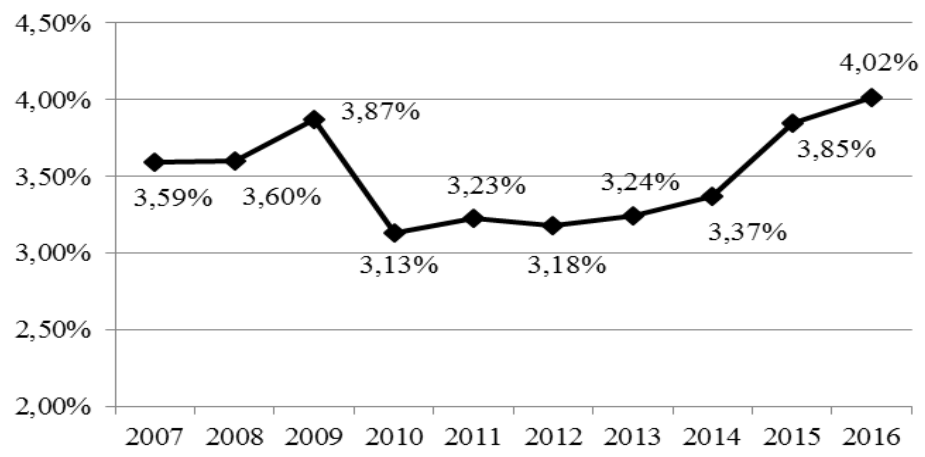

Рис. 1. Доля сельского хозяйства, охоты и лесного хозяйства за 2007-2016 гг. (в текущих ценах), \%

Сельское хозяйство России с 2000-х гг. является одной из наиболее активно развивающихся отраслей российской экономики. Так, на протяжении 10 лет отрасль по основным показателям характеризуется положительной динамикой развития: ростом валовой добавленной стоимости - в 2,5 раза, а в расчете на 1 работника — в 3,3 раза; инвестиций в основной капитал; финансовых вложений в 13,3 раза.

Таблица 1

Основные показатели по виду деятельности «Сельское хозяйство, охота и лесное хозяйство» за 2007-2017 гг.

\begin{tabular}{|l|l|l|l|l|l|l|l|l|l|l|l|}
\hline № & $\begin{array}{l}\text { Наименова- } \\
\text { ние }\end{array}$ & 2008 & 2009 & 2010 & 2011 & 2012 & 2013 & 2014 & 2015 & 2016 & 2017 \\
\hline 1 & $\begin{array}{l}\text { Валовая добав- } \\
\text { ленная стои- } \\
\text { мость } 1 \text { млрд р. }\end{array}$ & 1486,6 & 1502,4 & 1451,5 & 1944,5 & 1978,9 & 2162,2 & 2665,9 & 3203,5 & 3456,3 & 3694,7 \\
\hline 2 & $\begin{array}{l}\text { Число пред- } \\
\text { приятий и ор- } \\
\text { ганизаций, тыс. }\end{array}$ & 233,6 & 207,6 & 193,4 & 179,9 & 169,4 & 158,0 & 149,6 & 146,8 & 133,1 & 140,9 \\
\hline 3 & $\begin{array}{l}\text { Среднегодовая } \\
\text { численность } \\
\text { занятых, тыс. } \\
\text { чел. }\end{array}$ & 6675 & 6733 & 6622 & 6583 & 6467 & 6364 & 6247 & 5418 & 5374 & 5075 \\
\hline 4 & $\begin{array}{l}\text { Инвестиции в } \\
\text { основной капи- } \\
\text { тал, млрд р. }\end{array}$ & 399,7 & 325,2 & 303,8 & 445,9 & 476,4 & 487,7 & 510,3 & 505,8 & 611,2 & 400,0 \\
\hline 5 & $\begin{array}{l}\text { Основные фон- } \\
\text { ды, млрд р. }\end{array}$ & 2259,6 & 2566,9 & 2859,9 & 3127,2 & 3335,0 & 3671,8 & 3909,0 & 4285,1 & 4758,5 & 5791,6 \\
\hline 6 & $\begin{array}{l}\text { Степень износа } \\
\text { основных фон- } \\
\text { дов, \% }\end{array}$ & 42,2 & 42,2 & 42,1 & 42,8 & 42,5 & 42,7 & 43,5 & 41,6 & 41,2 & 38,2 \\
\hline
\end{tabular}

\footnotetext{
${ }^{1}$ Валовая добавленная стоимость представляет собой разницу между стоимостью произведенных товаров и услуг (выпуском) и стоимостью товаров и услуг, полностью потребленных в процессе производства (промежуточное потребление).
} 
С. Э. Раднаева, И. С. Мункуева, Д. Д. Санжиева. Анализ современного состояния и динамики развития сельского хозяйства и лекарственного растениеводства в России

\begin{tabular}{|c|c|c|c|c|c|c|c|c|c|c|c|}
\hline 7 & $\begin{array}{l}\text { Ввод в дей- } \\
\text { ствие основных } \\
\text { фондов }\end{array}$ & 303,4 & 282,7 & 310,9 & 380,1 & 385,5 & 424,3 & 424,6 & 449,4 & 606,3 & 657,8 \\
\hline 8 & $\begin{array}{l}\text { Финансовые } \\
\text { вложения } \\
\text { млрд р., в том } \\
\text { числе: }\end{array}$ & 71,3 & 89,6 & 154,0 & 177,5 & 193,8 & 222,6 & 374,1 & 582,6 & 792,4 & 944,8 \\
\hline & долгосрочные & 30,4 & 37,7 & 28,3 & 38,6 & 34,1 & 40,6 & 56,4 & 79,7 & 103,6 & 89,8 \\
\hline & краткосрочные & 41,0 & 51,9 & 125,7 & 138,8 & 159,7 & 182,0 & 317,7 & 502,9 & 688,8 & 725,5 \\
\hline 9 & $\begin{array}{l}\text { Валовая добав- } \\
\text { ленная стои- } \\
\text { мость на } 1 \text { ра- } \\
\text { ботника, тыс. p. }\end{array}$ & 222,7 & 223,1 & 219,2 & 295,4 & 306,0 & 339,7 & 426,7 & 591,3 & 643,2 & 728,0 \\
\hline 10 & Фондоотдача, р. & 0,66 & 0,59 & 0,51 & 0,62 & 0,59 & 0,59 & 0,68 & 0,75 & 0,73 & 0,64 \\
\hline
\end{tabular}

Объемы производства сельхозпродукции России в стоимостном выражении за последние 10 лет демонстрируют в целом устойчивые темпы роста с 2013 г., достигнув 5,654 трлн рублей в 2017 г. Причем растениеводство является ведущей отраслью сельского хозяйства России по объему валовой продукции свыше $50 \%$ от общего объема за последние 5 лет, начиная с 2013 г. Так, по состоянию на 2017 г. на растениеводство приходится $53,6 \%^{2}$ производства, животноводство составило $46,4 \%$.

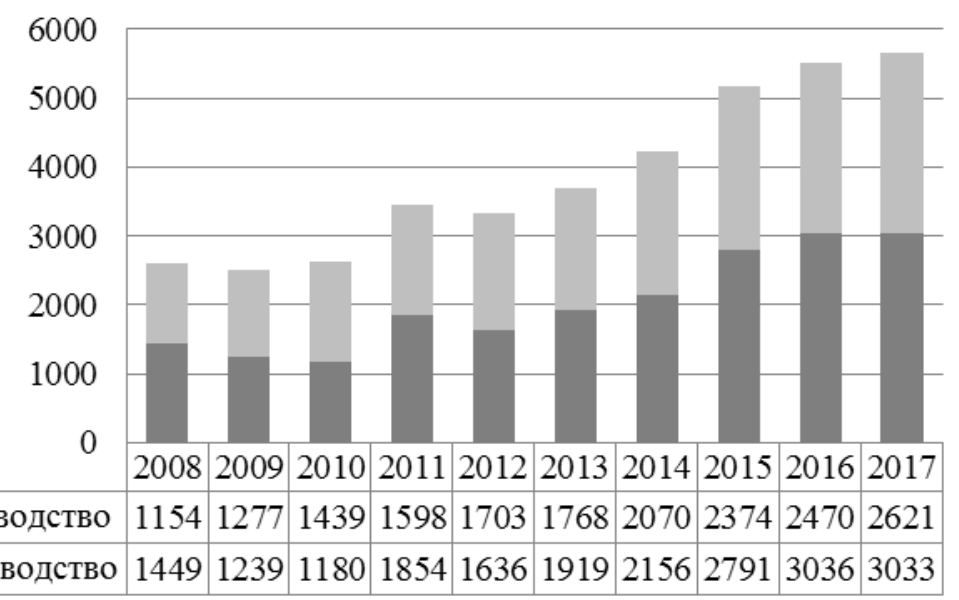

Рис. 2. Продукция сельского хозяйства России за 2008-2017 гг., млрд р. ${ }^{3}$

\footnotetext{
${ }^{1}$ Финансовые вложения, осуществляемые организациями, в зависимости от погашения займов и кредитов подразделяются на долгосрочные и краткосрочные.

${ }^{2}$ Агропродмаш-2019: 24-я международная выставка «Оборудование, технологии, сырье и ингредиенты для пищевой и перерабатывающей промышленности». URL: https://www.agroprodmash-expo.ru/ru/ui/17118/ (дата обращения: 14.12.2018).

${ }^{3}$ Основные показатели сельского хозяйства в России в 2017 году: бюллетень [Электронный pecypc] / Федеральная служба государственной статистики. URL: http://www.gks.ru/wps/wcm/connect/rosstat_main/rosstat/ru/statistics/publications/catalog/doc 1140096652250 (дата обращения: 14.12.2018).
} 
Следует отметить, что за 10 лет наблюдаются достаточно высокие темпы роста производства продукции растениеводства. Так, объем продукции растениеводства в стоимостном выражении увеличился более чем в 2 раза за рассматриваемый период. Ежегодные индексы производства продукции растениеводства с 2013 по 2017 г. демонстрировали стабильный рост, превышая индекс продукции животноводства и сельского хозяйства в целом (рис. 3).

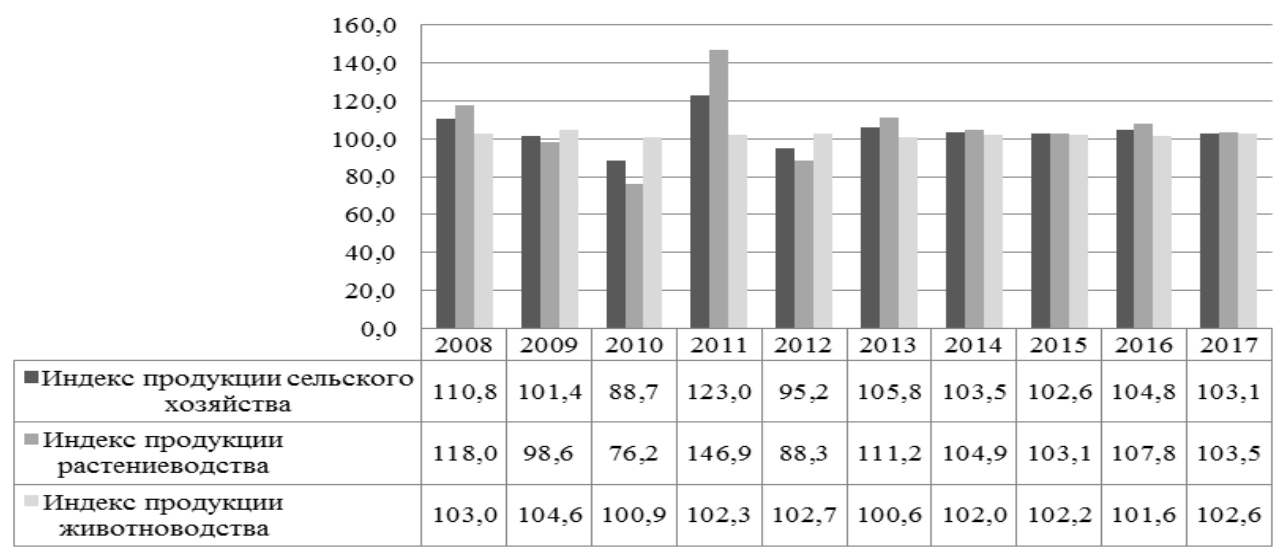

Рис. 3. Индексы продукции сельского хозяйства России хозяйств всех категорий за 2008-2017 гг. (в сопоставимых ценах), \%

Основными видами растительной сельхозпродукции в России являются зерновые культуры (пшеница, рожь, ячмень, рис и др.), овощеводство, технические культуры, в том числе кормовые. Главные технические культуры - подсолнечник (подсолнечное масло), сахарная свекла (сахар), лен (ткани и технические масла), картофель (крахмал). Некоторые растения выращивают специально для производства из них кормов - кормовые травы, силосные культуры, кормовые корнеплоды, фуражные зерновые.

Россия - это самый крупный экспортер сельскохозяйственной продукции, поставляющий на мировые рынки пшеницу, а также другие виды продовольствия и сырья. В 2017 г. экспорт злаков достиг рекордных объемов и составил 43,3 млн т, что на 27,6\% больше, чем в 2016 г. Объем экспорта пшеницы и меслина ${ }^{1}$ составил 33 млн т, что позволило России занять первое место в мире в рейтинге крупнейших стран-экспортеров данного продукта. По итогам 2016 г. экспорт продовольствия и сельхозтоваров вырос на 4,9\%, что составило 17,1 млрд долл. США, для сравнения экспорт оружия - 15,3 млрд².

\footnotetext{
${ }^{1}$ Меслин - смесь пшеницы и ржи, обычно в пропорции два к одному.

${ }^{2}$ О ходе и результатах реализации в 2017 году государственной программы развития сельского хозяйства и регулирования рынков сельскохозяйственной продукции, сырья и продовольствия на 2013-2020 годы: национальный доклад [Электронный ресурс] / Министерство сельского хозяйства Российской Федерации. M., 2018. URL: https://www.vedomosti.ru/economics/news/2017/10/24/739195-eksport-prodovolstviya (дата обарщения: 14.02.2018).
} 
С. Э. Раднаева, И. С. Мункуева, Д. Д. Санжиева. Анализ современного состояния и динамики развития сельского хозяйства и лекарственного растениеводства в России

Основными покупателями продукции российского АПК являются страны дальнего зарубежья, на которые в 2017 г. приходилось 76,7\% всей стоимости российского агропродовольственного экспорта, или 15,9 млрд долл. США. Лидерами среди стран-импортеров российской продукции АПК в 2017 г. стали Египет с объемом экспорта 1,78 млрд долл. США, Турция (1,78 млрд), Китай (1,77 млрд), Южная Корея (1,76 млрд), Казахстан (1,45 млрд), Беларусь (1,01 млрд) и др. ${ }^{1}$

По данным исследования центра «Делойт» в СНГ были получены следующие ключевые выводы о состоянии сельского хозяйства Р $\Phi^{2}$ :

- ТОП-3 стратегий сельхозпредприятий в 2017 г. - сокращение расходов, увеличение объемов производства, выход на новые рынки;

- ТОП-3 технологий процесса, внедренных представителями АПК РФ, прямая цепочка поставок, накопление генетической информации, точное земледелие;

- 78\% компаний говорят о положительном состоянии в отрасли;

- рентабельность продукции растениеводства за 2016 г. 32\% (в 2015 г. 36\%); для сравнения в животноводстве соответственно 11 и 16\%;

- 251 млрд р. - суммарная прибыль ${ }^{3}$ агропромышленных компаний за 2016 г.;

- 87\% прибыли компаний АПК за последние три года сформировано за счет субсидий, полученных от государства, это означает, что говорить о выходе проектов АПК на полную окупаемость еще преждевременно, а субсидии остаются одним из ключевых факторов в принятии инвестиционных решений в АПК;

- $-0,08$ - оценка эффективности государства в области поддержки АПК по итогам 2016 г. (рейтинг от -1 до +1$)$.

Лекарственное ${ }^{4}$, а также эфирномасличное растениеводство является одной из подотраслей растениеводства. Производимые технические культуры возделываются для получения технического сырья во многих отраслях промышленности медицинской, фармацевтической, парфюмерно-косметической, пищевой, хлебопекарной, кондитерской, консервной, ликероводочной, комбикормовой, химической, лакокрасочной, полиграфической, текстильной, кожевенной, металлургической, они также используются в ветеринарной практике.

Лекарственные растения служат для получения галеновых препаратов (экстрактов, водных, спиртовых, эфирных извлечений, густых, жидких, порошкообразных и твердых по консистенции) и соков. Галеновые препараты обычно готовятся из лекарственных растений, из которых невозможно выделить активные вещества в чистом виде.

\footnotetext{
${ }^{1}$ О ходе и результатах реализации в 2017 году государственной программы развития сельского хозяйства и регулирования рынков сельскохозяйственной продукции, сырья и продовольствия на 2013-2020 годы: национальный доклад [Электронный ресурс] / Министерство сельского хозяйства Российской Федерации. M., 2018. URL: https://www.vedomosti.ru/economics/news/2017/10/24/739195-eksport-prodovolstviya (дата обращения: 14.02.2018).

${ }^{2}$ Обзор рынка сельского хозяйства. Исследовательский центр «Делойт» в СНГ. 2017.

${ }^{3}$ Прибыль до налогообложения.

${ }^{4}$ Растения, содержащие фармакологически активные вещества и оказывающие то или иное терапевтическое воздействие на организм, называют лекарственными растениями.
} 
Природно-географическая среда и почвенно-климатические условия Российской Федерации являются благоприятными факторами для произрастания и возделывания широкой номенклатуры лекарственных растений. Из общей территории России, составляющей 17 млн км ${ }^{2}, 45 \%$ - леса, 19\% - пастбища, 13\% сельскохозяйственные угодья, то есть естественная среда обитания лекарственных растений в стране занимает 13,1 млн км².

Россия обладает значительным богатством и разнообразием растительных видов. На территории страны произрастает более 15 тыс. видов растений, многие из которых являются потенциальным источником сырья для производства лекарственных препаратов. Природные запасы лекарственного растительного сырья являются составной частью экономических ресурсов России, одним из факторов химико-фармацевтического производства.

Следует отметить, что в России значимость лекарственных растений была исторически высокой. Лекарственных трав, которые традиционно заготавливали, насчитывалось порядка 200-250 культур. В СССР перечень культивируемых трав был расширен: к 1940 г. существовали методики по возделыванию 10 видов трав, к 1976 г. - 50 видов. Площадь полей, занятых лекарственными растениями, достигала 30000-50000 га. Основными видами были: валериана лекарственная, ромашка аптечная, дурман обыкновенный, белена черная, наперстянка пурпурная и облепиха.

После резкого спада в конце 1990-х гг. размер посевных площадей, занятых под выращивание лекарственных растений в России, за последние годы характеризуется неравномерной динамикой. Периоды роста площадей под лекарственные культуры отмечаются в 2007 и 2013 гг., что составляет примерно 4-летний цикл. В 2016 г. площади составляли 8,6 тыс. га, с которых было собрано 6480 тонн лекарственного растительного сырья (рис. 4).

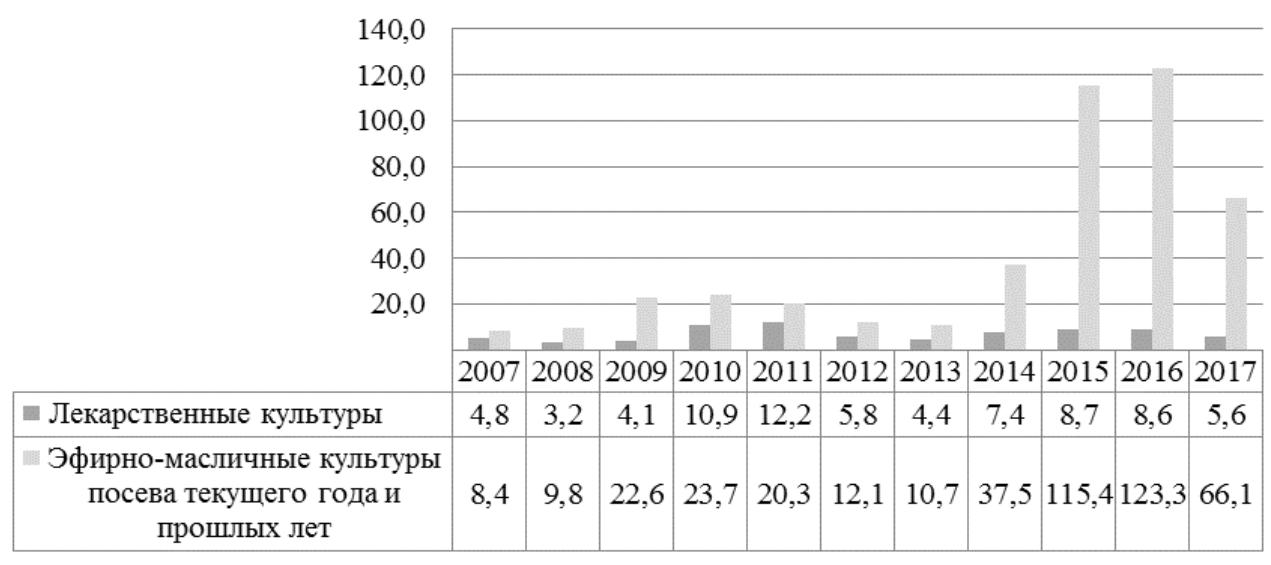

Рис. 4. Посевные площади лекарственных культур в хозяйствах всех категорий за 2007-2017 гг. в России, тыс. га ${ }^{1}$

\footnotetext{
${ }^{1}$ Посевные площади сельскохозяйственных культур в Российской Федерации: бюллетень (пересчитанные данные с учетом итогов ВСXП 2016). Ч. 1 [Электронный ресурс]. URL:
} 
С. Э. Раднаева, И. С. Мункуева, Д. Д. Санжиева. Анализ современного состояния и динамики развития сельского хозяйства и лекарственного растениеводства в России

Посевные площади лекарственных культур в России за 2017 г. незначительны, и по сравнению со всей посевной площадью и площадью, занятой под технические культуры, составляют соответственно 0,01 и $0,04 \%$.

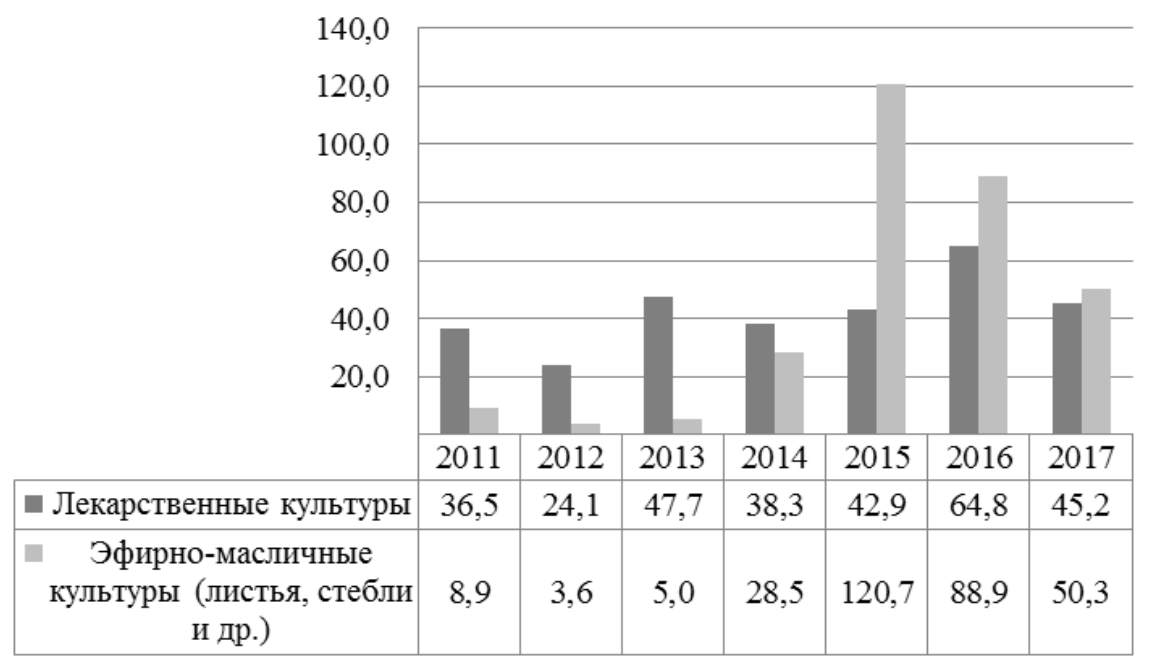

Рис. 5. Валовой сбор лекарственных и эфирномасличных культур в России хозяйств всех категорий за 2011-2017 гг., тыс. ц [4]

Валовые сборы лекарственных и эфирномасличных культур, несмотря на более существенные колебания размеров посевных площадей, с 2011 г. (начало учета данных Росстатом РФ) демонстрируют устойчивый рост по сравнению с валовыми сборами эфирномасличных культур с некоторым снижением в 2017 г.

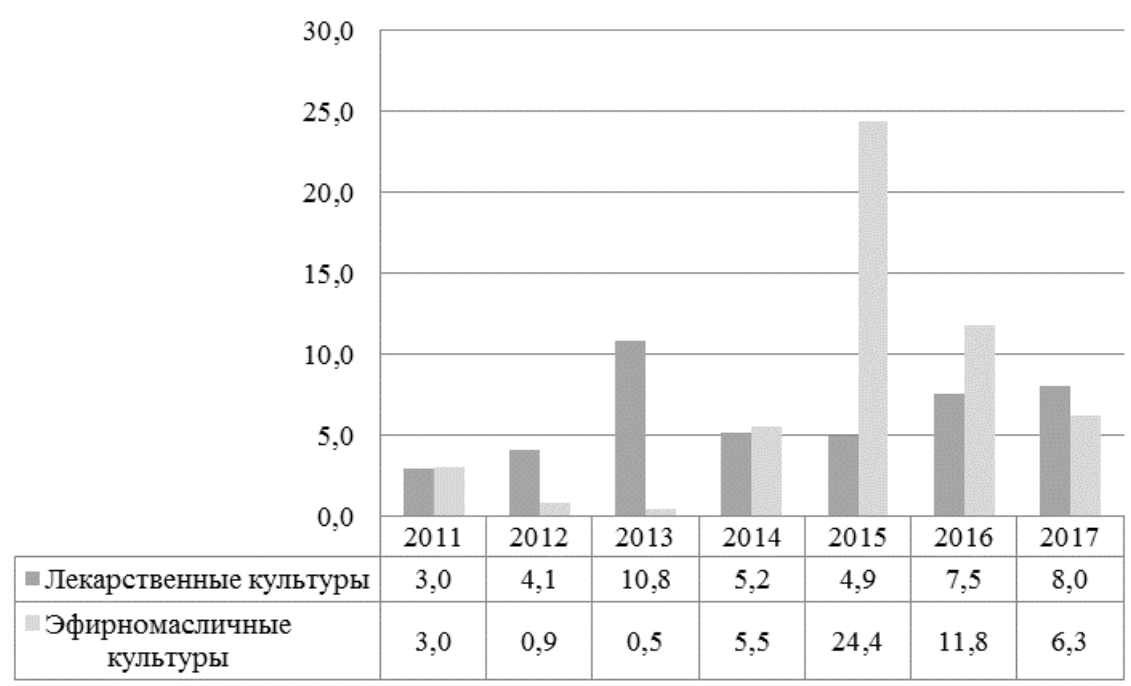

Рис. 6. Урожайность лекарственных и эфирномасличных культур в России хозяйств всех категорий за 2011-2017 гг., ц/га

http://www.gks.ru/wps/wcm/connect/rosstat_main/rosstat/ru/statistics/publications/catalog/doc 1265196018516 (дата обращения: 14.12.2018). 
Урожайность лекарственных культур за рассматриваемый период имеет тенденцию стабильного умеренного роста, а также превышает или составляет примерно равные значения с урожайностью эфирномасличных культур на протяжении 5 лет из 7.

В России большая часть лекарственных растений выращивается в крупных предприятиях: ООО «Вистерра», НПФ «Алтайский букет», ООО «Фитосовхоз "Радуга"», ООО «Моя мечта», ООО «Парафарм», ЗАО «Эвалар» и др. Большинство из них лекарственные растения выращивают для собственных нужд - производство готовой продукции. На крестьянские (фермерские) хозяйства приходится только 1/3 площади всех посевов лекарственных культур [1], что представляет собой значительный потенциал для роста отрасли за счет привлечения большого количества участников из числа фермеров.

Опыт стран Европы, где посевные площади составляют порядка 70 тыс. га, показывает, что основные объемы сырья выращиваются в фермерских или специализированных хозяйствах. Так, в Польше, которая занимает одно из лидирующих мест в Европе по культивированию лекарственных растений, ежегодно на площади около 30 тыс. га их выращивает около 20 тыс. фермеров. При этом у каждого фермера площади под лекарственные растения занимают $0,5-2,5$ га, в зависимости от вида растения, а в случае специализированных хозяйств площадь может достигать 6-10 га. В Китае лекарственные и ароматические растения выращивают как большие компании на тысячах гектарах, так и фермеры на небольших участках в 1-5 га [1].

Основными проблемами лекарственного растениеводства в России являются проблемы, характерные для всего сельского хозяйства, а также ряд специфических, таких как отсутствие поколения предпринимателей (как следствие колхозной системы), нехватка квалифицированных кадров для отрасли, негативные тенденции в селекции и семеноводстве лекарственных растений, недостаток и/или зачастую отсутствие специализированной техники, нехватка инвестиционных и оборотных средств, низкие цены на импорт.

При содействии Ассоциации производителей и потребителей традиционных растительных лекарственных средств ${ }^{1}$ (АППТРЛС) и при поддержке Министерства сельского хозяйства РФ существенно расширены география и номенклатура вводимых в культуру лекарственных культур. Так, в 2018 г. насчитывалось 12 площадок на территории страны, которые продолжают опытное выращивание уже более 50 наименований растений, тогда как в 2017 г. — всего 16 [2].

В последние годы возрождению отрасли лекарственного растениеводства России уделено внимание в рамках реализации проекта «Возрождение отрасли лекарственного растениеводства в РФ» направления «Превентивная медицина» Дорожной карты (ДК) «ХелсНет» Национальной технологической инициативы (НТИ) - развитие рынка персонализированных медицинских услуг и лекарственных средств, обеспечивающих увеличение продолжительности жизни, по-

\footnotetext{
${ }^{1}$ АППТРЛС образована в июне 2017 г., объединяет юридических и физических лиц, вовлеченных в процесс лекарственного растениеводства, производства и потребления традиционных растительных лекарственных средств. Среди участников ассоциации крупнейшие торговые и сельхозпредприятия, вузы, медицинские и фармацевтические организации.
} 
С. Э. Раднаева, И. С. Мункуева, Д. Д. Санжиева. Анализ современного состояния и динамики развития сельского хозяйства и лекарственного растениеводства в России

лучение новых эффективных средств профилактики и лечения различных заболеваний. Также правительством РФ поставлена перед фармацевтической отраслью важная задача импортозамещения медицинских препаратов. ДК утверждена решением президиума Совета при Президенте РФ по модернизации экономики и инновационному развитию России 20 декабря 2016 г. и подписана председателем правительства Д. А. Медведевым 29 декабря 2016 г.

Согласно ДК к 2035 г. в России планируется запустить не менее 25 научнообразовательных агротехнопарков по производству концентрированных жидких, сухих и гранулированных растительных лекарственных субстанций и препаратов и создать до 300 тыс. фермерских хозяйств, объединенных в сельскохозяйственные производственные кооперативы, которые займутся выращиванием, первичной переработкой и хранением лекарственного сырья. ДК предусмотрено создание «международной сетевой платформы по координации выращивания экологически чистых лекарственных растений и производства концентрированных жидких, сухих и гранулированных растительных лекарственных субстанций и препаратов» ${ }^{1}$.

Таким образом, на фоне положительной динамики развития сельского хозяйства в лекарственном растениеводстве за последние 7 лет наблюдаются незначительные объемы производства по сравнению с другими сельскохозяйственными культурами. Отрасль получает свое развитие в настоящее время в основном за счет крупных фармацевтических компаний, заинтересованных в возделывании лекарственных трав для собственных нужд, в качестве и удешевлении лекарственного растительного сырья.

В то же время природно-географическая среда и почвенно-климатические условия России, значительное богатство, природные запасы и разнообразие растительных видов, существующая культура потребления фитопрепаратов и история возделывания лекарственных растений во времена СССР, обширный спектр применения лекарственного растительного сырья во многих отраслях промышленности являются важными предпосылками возрождения лекарственного растениеводства на общероссийском уровне. Очевидно, что становление отрасли лекарственного растениеводства имеет значительный потенциал развития за счет вовлечения в отрасль большого количества участников из числа малых и средних сельхозпредприятий и хозяйств.

\section{Литература}

1. Козко А. А., Цицилин А. Н. Перспективы и проблемы возрождения лекарственного растениеводства в России [Электронный ресурс]. URL: https:/cyberleninka.ru/ article/n/perspektivy-i-problemy-vozrozhdeniya-lekarstvennogo-rastenievodstva-v-rossii (дата обращения: 18.01.2019).

2. Погонцева Е. Российские производители лекарственных растений за год увеличили номенклатуру в 3 раза [Электронный ресурc]. URL: https://www.rvc.ru/pressservice/media-review/nti/131724 (дата обращения: 18.01.2019).

\footnotetext{
${ }^{1}$ Региональный стандарт НТИ [Электронный ресурс]. URL: http://www.nti2035.ru (дата обращения: 18.01.2019).
} 


\section{ANALYSIS OF THE CURRENT STATE AND DEVELOPMENT OF AGRICULTURE AND MEDICINE PLANT GROWING IN RUSSIA}

Svetlana E. Radnaeva

Cand. Sci. (Econ.)

E-mail: radnasv@gmail.com

Irina S. Munkueva

Cand. Sci. (Econ.), A/Prof.

E-mail: mishka81@yandex.ru

Darima D. Sanzhieva

Cand. Sci. (Econ.)

E-mail: daricha.s@mail.ru

Dorzhi Banzarov Buryat State University

24a Smolina St., Ulan-Ude 670000, Russia

The article analyzes the current state and dynamics of agriculture development in the Russian Federation, as well as medicinal plant growing as its sub-sector. We have given the key indicators, reflecting the active development of agriculture for the last 10 years, such as growth of gross value added, significant increase in fixed capital expenditures and financial investments, record export volumes of grain crops. Such trends in agriculture development, as strategies of agricultural producers aimed at reducing costs, growth in production, entry into new markets, etc., are revealed. We have estimated the key indicators of the current state of medicinal plant growing, including acreage, gross yield and yield of medicinal and essential oil crops, for the last 7 years, and identified the major problems and prerequisites for the revival of medicinal plant growing in the framework of "Helthnet" roadmap, developed by the National Technology Initiative.

Keywords: agriculture; medicinal plant growing; herbal substances; "HelthNet" roadmap of the National Technology Initiative. 